\title{
The Performing Arts in Second Language Acquisition
}

\author{
A Report on the Experience of Dramatizing a Novel
}

\author{
Mark Lauer
}

\begin{abstract}
This paper is a report on the experience of dramatizing Hans Peter Richter's novel Damals war es Friedrich (1961). Subsequent to the discussion of the novel in an upper division German class, students and I worked on a dramatized version of the text. The play was performed in the Black Box Theater at Georgetown University, Washington D.C., on April 11, 2006. The first part of the report will illustrate how the work on the play was embedded within the context of a literacy approach towards teaching German as a foreign language. In addition to outlining the benefits of including a theater performance in language education, as experienced during the rehearsals and the performance of the play, the second part of the report will discuss how the project was carried out.
\end{abstract}

The Performing Arts in Second Language Acquisition: A Report on the Experience of Dramatizing a Novel

Mark Lauer

\section{Embedding the Performance of a Play in a Literacy-Oriented Teaching Approach}

As a German language instructor, I aim to guide learners in becoming literate users of the German language in both private and public discourses. This literacy orientation involves an active, challenging approach to speaking and textual practice. Together with my teaching experience both within the Developing Multiple Literacies curriculum of the Department of German at Georgetown University (GUGD) and at Mount Holyoke College, MA, I have experienced that a literacy orientation is best integrated into a curriculum that is geared towards overcoming the traditional division between language and content.

While I believe that instructed learning within a classroom environment is essential for developing advanced language skills, I am convinced that my students and I need to think beyond the scope of the classroom. This is why I have fostered my students' insight into the target language outside the 
classroom through organizing and directing a play performance. The idea for writing a play and putting it on stage emerged from the classroom discussion of Hans Peter Richter's novel Damals war es Friedrich, first published in 1961. The text was part of a unit on the influence of Germany's past on the present time in an upper division German course ${ }^{1}$ entitled Text in Context: Reading Germany, which I taught in the spring of 2005.

The Text in Context course targets listening comprehension skills and fosters reading, writing, and speaking abilities through summarizing, critiquing, debating, and giving presentations. The main goals of the course are to increase students' fluency, complexity, and accuracy of their speaking and writing skills (see also Bygate 1999). The course is conceptualized to complete the sequenced part of the GUGD's integrated, content-based language program, which Bollag describes as a "model for a new approach that is beginning to transform how foreign languages are taught" (Bollag 2007). ${ }^{2}$ As such, it concludes an integrated, content-oriented and task-based approach that familiarizes students with different, but reappearing genres embedded in a variety of interrelated themes (see also Richards and Nowicki 1998a, 1998b).

The aim of the sequenced structure of interrelated themes covered in the course is to go beyond short-term rote memorization. The course fosters the assimilation of cultural and language knowledge in a way that allows for the re-application of familiar structures to related contexts and to novel situations. Following this approach, I familiarize students with the tools necessary to examine and question the values and beliefs that lie beneath the surface of written and spoken discourses. Tools, such as the use of Wortfelder instead of vocabulary lists (see Appendix A) and specifically designed tasks that combine content knowledge with language instruction (see Appendix C) help students to contextualize the assigned reading. Theme-related vocabulary learning and task oriented presentation skills were embedded in the discussion of Richter's novel Damals war es Friedrich, which was one of the texts we read during the first unit of the course.

The first part of the course familiarizes students with fictive personal stories covered in Richter's novel, which concerns the prosecution of Jews in Germany before and during WWII. Richter's novel tells the story of a Jewish boy named Friedrich and an unnamed Aryan narrator, two boys born days apart in 1925 who live in the same apartment building in Berlin. As the story progresses, the narrator describes the increasingly harsh realities of their friendship leading to a tragic end within Hitler's Germany. A variety of assignments (e.g. an instructed

\footnotetext{
${ }^{1}$ In this specific case, students had either six semester of language instruction within the non-intensive track of the sequenced Georgetown University "Multiple Literacies" curriculum or three semesters on the intensive track. Students entering the curriculum with previous knowledge of German are placed within a certain level of the sequence depending on their placement results.

2 The Georgetown University German Department provides a detailed description of its Multiple Literacies Curriculum at its homepage: http://www1.georgetown.edu/departments / german/programs/undergraduate/curriculum/36465.html. For a sample discussion on how to design a content-based language course see also Eigler 2001: 107pp.
} 
analysis of the chapters) that complement the reading of Richter's novel helps students enhance their vocabulary through a meaningful discussion of the text.

Having discussed the historic developments during WWII on a narrative level against the background of Richter's novel, the classroom focus subsequently shifts and progresses to the analysis of texts approaching the topic at the public level. Immediately following the discussion of Richter's novel is an analysis of former president of Germany Richard von Weizsäcker's (Bundespräsident 1984-1994) famous 1985 speech, ${ }^{3}$ whereby he addresses the responsibility to remember the past. The discussion of von Weizsäcker's speech builds upon and extends the content and language features students have become acquainted with when working with Richter's novel. ${ }^{4}$

At the beginning of our work with Richter's novel, I introduce students to the historic time-table of the events leading up to and occurring during WWII, which is attached to the main story in Richter's novel. ${ }^{5}$ This time-table helps students to situate the content of the different chapters within its respective historic context as the story of the friendship progresses. Emphasizing the connection between the fictive story and historic events, I raise students' awareness with regard to the increasing reduction and restriction of legal rights in Germany between 1925 and 1942, the time-frame of the novel's plot. It has proven helpful to ask students what basic, fundamental rights (Grundrechte) they have in the U.S. and to list these on the board, followed by the coinciding terminology in German. While listing students' suggestions on the board, I introduce them to different expressions and phrases related to the topic of giving/taking away rights, which they subsequently must learn and use when discussing the plot of the chapters. ${ }^{6}$ A task-sheet asking students to combine the information on the time-table with the expressions they have learned when listing and discussing a variety of rights encourages students to construct meaningful sentences while referring to the plot of the novel. ${ }^{7}$ On the micro-level, this will lead to an increase in the level of automaticity through which they develop their foreign language skills (see also Taguchi, Gorsuch, and Sasamoto 2006). This approach will assist learners in gradually becoming able to use certain parts of their foreign language knowledge so automatically that they are not even aware of

\footnotetext{
${ }^{3}$ The speech was held in the Deutscher Bundestag on May $8^{\text {th }} 1985$ and is considered to be one of the most influential speeches on approaches to remember the German past. The speech is published on the website of the Deutscher Bundestag at: http://www . bundestag. de/ geschichte/parlhist/dokumente/dok08.html.

${ }^{4}$ Other texts covered in unit one of the course include Schneider, Peter (2001): Und wenn wir nur eine Stunde gewinnen. Berlin: Rowohlt (Preface and chapter one); Jacobus, Hans (Die Zeit, 11.11.1994): "Menschen ohne Grab. Ein nachdenklicher Herbstspaziergang über Europas größten jüdischen Friedhof in Berlin-Weißensee."; Hermlin, Stephan: "In einer dunklen Zeit." In: Marcel Reich-Ranicki (ed.) (1984): Verteidigung der Zukunft. Deutsche Geschichten 19601980. München: dtv; Celan, Paul (1952): „Todesfuge.“ Mohn und Gedächtnis. Stuttgart: Deutsche Verlagsanstalt.

${ }^{5}$ See Appendix B.

${ }^{6}$ For a sample overview on the collection of rights and the attached expressions, please take a look at Appendix A.

${ }^{7}$ See Appendix C for the task-sheet.
} 
the fact that they are doing this.

Progressively moving through three different units, ${ }^{8}$ students improve their writing and speaking skills by appropriately deploying language knowledge within the context of explicitly formulated tasks (see also Mislevy and Steinberg 2002). Detailed feedback on the first draft of written assignments allows learners to rework their submissions before handing in the final version. With regard to the presentation of speaking tasks, ${ }^{9}$ a review of students' outlines and a discussion of the structure of the presentation during office hours preceding the class meetings have led to rewarding outcomes for the classroom audience as well as the presenter.

The positive outcome of students' language learning, along with the stimulating discussion of Richter's novel in the first unit, led me to reflect on how the principles underlying fluency and automaticity in a foreign language environment could be improved even further. Increased automaticity through the incorporation of a variety of genres ${ }^{10}$ resulted in highly developed language abilities. However, the repetition of complex sentence patterns and vocabulary items accompanied a teaching approach that was, all too often, centered on the instructor. Offering students the opportunity to participate in a play based on Richter's novel developed into a successful tool to complement my literacy approach toward language learning.

During the work on the play, students did not only enjoy performing as actors/actresses, but they also wrote one of the scenes themselves, ${ }^{11}$ which was based on a task as part of the class discussion of the novel. Creating a scene based on one of the writing assignments they had completed for class developed into an additionally rewarding learning tool. In doing so, students transferred their classroom knowledge to a new setting and succeeded as language learners outside the classroom.

\section{Improving Second Language Acquisition through Dramatizing a Text}

Following Schewe, who defined foreign language (FL) teaching as both a 'scientific' and 'artistic' discipline, while encouraging FL instructors to see themselves not only as scientists but also as artists (see Schewe 1993: 39), I began work on a dramatized version of Richter's novel during the winter break

\footnotetext{
8 The course covers the discussion of narrative discourses in the first unit (see above), leading progressively toward public discourses. The following two units of the course focus on the German education system and education reform in Germany (Hochschulsystem und Hochschulreform), followed by an analysis of Germany's role in the process of European integration (Europäische Integration/Deutschland und Europa) in unit three of the course.

${ }^{9}$ Speaking task include, among others, the presentation of chapters according to a modeled presentation on the instructor's part.

${ }^{10}$ As an example, see the discussion of the novel, newspaper articles, excerpts of short texts by Stephan Hermlin and Peter Schneider, and Paul Celan's poem Todesfuge.

11 See Appendix E.
} 
of 2005. The straightforward time-line of the plot, in addition to an extensive use of direct speech in the novel, proved beneficial during the work on the play. Due to the rather short scope of the chapters of the novel, it was necessary to combine certain chapters into one scene, in order to present the scenes in a timely format of at least three minutes each. This minimum time length was chosen based on the assumption that shorter scenes would not provide enough time for the audience to adjust to the intensity of the plot. Instead of presenting 32 scenes directly corresponding to the number of chapters in the novel, the final performance consisted of eleven scenes covering nearly one hour of total performance time.

While working on the play, I asked the GUGD for potential support of the project. The department kindly offered its help in terms of providing me with a budget that would cover essential costs such as making copies of the play and creating flyers to be distributed to announce the play, setting up contacts with the Performing Arts Center on campus, and providing light refreshments during rehearsals. Upon completion of the dramatized script, I organized rehearsals and directed the performance of the play as an extracurricular activity, in collaboration with the Performing Arts Center at Georgetown University.

Most of the participating students were familiar with the original story, having read the novel in class. However, familiarity with the novel was not a prerequisite for participating in the play. I purposely left participation in the play open to all students of various German language levels, in order to attract as many interested students as possible. With thirteen different figures appearing in the play, of which some played a part in only one scene, I also encouraged students at the beginning and intermediate language levels to participate in the play.

At the beginning of the rehearsals, we met once a week in order to practice selected scenes. I had prepared a schedule that did not require all participants of the play to be present during each rehearsal. Taking into account that students were voluntarily committing their time during the evening hours, I did not want to overwhelm them with additional work. Nevertheless, I made it clear to the students from the beginning that they would need to firmly commit to participation in the play. This was necessary to ensure the realization of the final goal, namely the performance of the project in front of an audience.

Originally, I intended to have the play performed as a stage reading. In this scenario, students would have stood on stage with a copy of the script in hand, reading their parts out loud. Through repetition of the scenes during rehearsals, I had hoped to create a familiarity with the plot structure, along with a fluency in the language performance that would allow us to progressively work on elements such as intonation and mimic expressions. The outcome of the rehearsals and the performance exceeded my expectations by far, and convinced me even more of the advantages that lie in integrating the performance of a play into the process of foreign language learning.

Although a stage reading would also have been a promising start for incorporating a play into the process of second language acquisition, students 
quickly developed the ambition to play their parts without using the script or notes. During the rehearsals, they recognized the necessity of working on a clear and correct pronunciation and intonation when practicing their lines. In this context, Ronke has pointed out that

in a drama-oriented FL class, the motivation to practice ... linguistic features also increases because the learning situation (e.g., role plays, improvisations, plays or scenes of a play) are interactive and are acted out with or in front of class members or a wider audience. Both the 'actor' and the 'foreign language learner' need to watch how they say things so they can be understood. The audience can give immediate feedback, and there is the realization that one day the student may face an actual target language audience. (Ronke 2005: 118)

Since the students were somewhat hesitant to speak in a loud and clear voice at the beginning of the rehearsals, I had to remind them to speak louder in order "to fill the room" with their performance. Shortly afterwards, students started giving each other helpful feedback regarding the volume of their voices and the way their peers moved on stage. Students discussed how different scenes should be spoken, acted, and staged (see also Ronke: 47). Even though they sometimes switched back to English when talking about their acting, they used the target language for their meta-discussion more and more often during the rehearsals. One explanation for this may be my use of the target language throughout the play rehearsals. I am also convinced that the students' strong commitment and willingness to learn the language, in addition to their excitement over the project, contributed to their constant increase in using the target language during the rehearsals.

The first scene of the play only consisted of one line of direct speech, in which the anti-semitic landlord orders his wife to bring him a chair ("Den Stuhl!"). Aside from this one line, the scene was acted out in silence. In the script, the scene read as follows:

(Der Vorhang öffnet sich. Man sieht den Vorgarten eines Mietshauses und die davor vorbeiführende Straße. Herr Resch betritt von links die Bühne. Er schreitet langsam auf einen Gartenzwerg in der Mitte der Bühne zu. Als Herr Resch in der Mitte der Bühne angelangt ist, hält er inne. Er dreht sich in die Richtung, aus der er gekommen ist.)

Herr Resch. (herrschend):Den Stuhl!

Frau Resch folgt ihrem Mann, mit beiden Händen einen Stuhl tragend, rasch nach. Sie platziert den Stuhl rechts neben dem Gartenzwerg. Herr Resch setzt sich schnaufend auf den Stuhl, während Frau Resch die Bühne rasch wieder verlässt. Herr Resch und der Gartenzwerg blicken für eine Weile beide in Richtung des Publikums. Vor Herrn Resch gehen nun rechts und links einige Passanten grüßend vorbei, die Herr Resch mustert, ohne selbst zu grüßen. Nach einer Weile steht er unter sichtlicher Anstrengung keuchend und prustend auf, den Gartenzwerg rechts herum umkreisend. Er bleibt neben dem Gartenzwerg stehen und betrachtet den Gartenzwerg genauer, um schließlich ein Taschentuch aus der Hosentasche zu ziehen und dieses mit Speichel zu 
befeuchten. Langsam und beschwerlich beugt er sich vornüber und poliert die Zipfelmütze des Gartenzwergs, als Herr und Frau Schneider grüßend an ihm vorbei gehen. Kurz aufblickend verfinstern sich ansichtig der Schneiders seine Gesichtszüge. Er spuckt nun am Taschentuch vorbei laut auf den Boden und schiebt in gebückter Haltung sein Gesäß in Richtung der Schneiders. Kopfschüttelnd gehen die Schneiders weiter und verlassen die Bühne. Herr Resch setzt sich wieder auf den Stuhl und schaut in Richtung Publikum. Der Vorhang fällt.

Agreeing with Ronke, who argues that it is "especially important to use techniques that foster the awareness of nonverbal language and to practice kinesics in combination with spoken language" (Ronke: 101), I created the first scene of the play such as to include only a few elements of direct speech. In doing so, I intended to emphasize the artistic component of the enterprise, as well as to alleviate students' potential fear of taking part in a play performed in a foreign language. ${ }^{12}$

On the language level, students learned a variety of new words and expressions, which I acted out for them. The focus here was on verbs describing movements and mimic expressions, such as "die Bühne betreten/verlassen, langsam schreiten, inne halten, sich umdrehen, rasch folgen, den Gartenzwerg umkreisen, sich vornüber beugen, in gebückter Haltung sein, jemanden mustern, etwas betrachten, jemanden/etwas anschauen, auf jemanden/etwas schauen, den Kopf schütteln, aufblicken, herrschen, keuchen, prusten, spucken, einen verfinsterten Blick haben."

The subsequent scenes of the play consisted of dialogues between two or more people, but also required students to act in a creative way. The second scene, e.g., takes place in front of the landlord's house and shows Friedrich, the Jewish protagonist of the play, playing in the snow with his mother:

(Der Vorhang öffnet sich. In der Mitte der Bühne steht der Gartenzwerg. Auf der linken Seite der Bühne sieht man, wie Herr Resch, den Rücken zum Publikum gedreht, Schnee zur Seite schaufelt. Frau Rosner betritt von rechts, die Hand ihres Sohnes haltend, die Bühne. In der anderen Hand hält sie eine Einkaufstasche. Hans hält seine Mutter zurück, so dass sie beide stehen bleiben)

Hans: Mutter, es schneit so schön. Ich möchte draußen bleiben und im Schnee spielen.

Frau Rosner: Das glaub ich dir. Aber erst kommt die Arbeit, mein Junge, dann darfst du in den Schnee.

Frau Rosner. (lachend):Tröste Dich! Es wird noch mehr, viel mehr fallen!

(Von links läuft Friedrich auf die Bühne und springt mit beiden Füßen in den Schnee. Behutsam macht er einen sehr großen Schritt, ohne Notiz von den Anwesenden zu nehmen. Er dreht sich um, bückt sich und betrachtet seine

\footnotetext{
12 Ronke has also pointed out that "if students are to achieve communicative competence, language teachers should teach both verbal and nonverbal language, as these modes of communication complement and support each other by conveying important meaning." (Ronke 2005: 100-101)
} 
Sohlenabdrücke, während Frau Rosner und Hans ihm dabei zuschauen. Dann richtet er sich auf. Er legt den Kopf bis weit in den Nacken zurück, öffnet den Mund und lässt es hinein schneien. Dann guckt er wieder auf seine Spur. Er dreht sich um und beginnt, die Augen auf den Boden gerichtet, langsam eine Fährte in den Schnee zu stapfen.)

Hans: Mutter, Friedrich spielt schon im Schnee. Darf ich auch?

Frau Rosner: Du musst warten lernen. Hab noch ein wenig Geduld.

(Langsam, jegliches Geräusch vermeidend, schleicht sich Frau Schneider, die Bühne von links betretend, an ihren Sohn heran, der sie nicht wahrnimmt. Als sie ihn erreichthat, wirft sie ihm mit beiden Händen Schnee über den Kopf. Friedrich schreit auf und schüttelt sich. Er blickt sich um. Als seine Mutter ihm immer mehr Schnee entgegenschleudert, duckt er sich lachend. Mit gespreizten Fingern schützt er sein Gesicht. Mit einem Sprung steht er vor seiner Mutter. Er versteckt seinen Kopf unter ihrem Mantel und presst sich fest an sie, um dem Gestöber zu entfliehen. Frau Schneider hockt sich hin. Lachend drückt sie Friedrich an sich und klopft ihm den Schnee aus dem Mantel. Dann fasst sie ihn bei den Schultern und tanzt mit ihm im Schnee herum.)

Hans: Auch Frau Schneider ist bei Friedrich im Schnee. Lass mich doch bitte hier bleiben und mit ihnen spielen.

Frau Rosner: Quäl mich doch nicht, Junge.

(Die Schneiders spielen weiter im Schnee. Sie werfen Schneebälle, wälzen den Schnee zu großen Schneekugeln etc.)

Hans. (bettelnd): Mutter, Schneiders schlittern. Bitte lass mich doch!

Frau Rosner: Erst die Schulaufgaben, Hans. Danach gehn wir wieder nach draußen.

(Frau Rosner und Hans schauen den Schneiders, die kreischend und johlend ihren Spaß genießen, eine Weile zu.)

Hans: Mutter, sie bauen einen Schneemann!

Frau Rosner: Nun gut, lass uns Frau Schneider fragen, ob sie eine halbe Stunde auf dich aufpasst und mit euch beiden im Schnee spielt.

Hans. (erfreut): Mutter, hab' vielen Dank!

Frau Rosner. (halb mahnend, halb schmunzelnd): Aber nur eine halbe Stunde, Hans!

(Friedrich hat sich in der Zwischenzeit ganz in die Nähe des Gartenzwergs begeben und führt eine Schneeballschlacht mit seiner Mutter. Frau Rosner hält Hans weiter bei der Hand und geht auf Frau Schneider zu. Kurz bevor sie Frau Schneider erreicht, dreht sich Herr Resch zu den Geschehnissen und sieht Friedrich bei seinem Gartenzwerg.)

Herr Resch. (brüllend):Willst du dich wohl von meinem Gartenzwerg fortmachen, du Judenbengel, du!

(Frau Schneider und Friedrich halten mit dem Spiel inne und starren in Herrn Reschs Richtung. Frau Rosner und Hans bleiben ebenfalls stehen und schauen auf Herrn Resch. Nach einer kurzen Weile reißt Frau Rosner ihren Sohn am Arm und geht weiter.) 
Hans: Mutter, ich wollte aber doch...

Frau Rosner: Komm!

(Frau Schneider und Friedrich schauen nun auf Frau Rosner und Hans. Frau SchneidersBlick kurz erwidernd bleibt Frau Rosner stehen. Frau Rosner hält dem Blick Frau Schneiders jedoch nicht lange Stand und zieht Hans erneut hinter sich her.)

Frau Rosner. (mit lauter Flüsterstimme): Nun komm endlich, Hans!

(Sie verlassen die Bühne. Frau Schneider und Friedrich drehen sich wieder zu Herrn Resch, der, Schnee schaufelnd, den Geschehnissen wieder den Rücken zugekehrt hat.)

Frau Schneider. (ihre Hand ausstreckend): Friedrich, lass uns nach drinnen gehen.

Friedrich. (läuft zu ihr und ergreift ihre Hand): Ja, Mutter.

(Sie verlassen die Bühne. Für einen Moment sieht man Herrn Resch weiter Schnee schaufeln. Dann fällt der Vorhang.) In Richter's novel, the unnamed narrator and his mother watch Friedrich and his mother playing in the snow from inside the house. The rather basic facilities of the Black Box Theater, consisting of a square room with black walls and a flat floor, which we had mainly chosen in order to keep rehearsal and performance costs low, led me to deviate from the original text. Instead of creating a scene in which Hans Rosner and his mother would watch the Schneiders' activities in the snow from inside the house, which would have required us to build a wall and a window, both parties were placed on the street outside the house. This setting was implied by the presence of a garden gnome, which was put in the middle of the stage. The stage spacing allowed the two acting parties to keep a significant distance between one other (Hans Rosner and his mother vs. Friedrich Schneider and his mother).

During the rehearsals, it turned out that the sparse equipment of the Black Box Theater and the rather dark atmosphere of the setting not only helped to facilitate students' acting, but it also nicely supported the dramatic plot structure. Instead of focusing on costumes or properties, the focus was on the students and their acting. This atmosphere did not go unnoticed by the students, and served to encourage them to constantly improve their performance.

Students realized that memorizing a line helped them to better focus on the intonation and the performance aspect of the play, rather than on the line itself. This realization led to a positive group dynamic, the result being that students began to memorize their lines, allowing them as actors to independently play out their parts. The process of memorizing lines led to an increased automaticity of accurate language use in a creative setting, which can be described as a 'controlled processing' (attentively practiced) followed by an 'automatic processing' (making skills a routine) (see Schiffrin and Schneider 1977, cited in Ronke 2005: 49).

The process of language learning during the play rehearsals was a contextualized language learning whereby students gave meaning to spoken discourses outside the classroom. The contextualized aspect was two-folded for the 
students who had discussed the novel in the class. They were not only able to relate the scenes of the play to the classroom-discussion of the novel, but they also realized how each scene built on the next one in order to create a smooth transition for the audience. Students who had not read the novel previously also benefited greatly from the meaningful transition of the scenes. They realized that the communication on stage had a 'real' aspect to it, which did not have the artificial character of exercises so often practiced in a foreign language classroom. It is especially for this reason that I consider theater performances in a foreign language environment a great tool to support contextualized language learning.

With the performance date approaching, rehearsals were scheduled twice a week, requiring all participants to be present during the last two weeks of practice. In addition to the outlined advantages I experienced regarding the improvement of students' speaking performances, the inclusion of a written assignment created by participants of the play proved to be a stimulating way to encourage foreign language learning outside the classroom atmosphere.

One of the four writing assignments that were part of the discussion of Richter's novel within the classroom had been to write a fictitious letter from the perspective of the narrator's mother. ${ }^{13}$ In the letter, one of Friedrich's relatives living in the U.S. is informed by the narrator's mother of the circumstances leading to Frau Schneider's death. A description of personal behavior (e.g., failure to help; the question of guilt) was an essential component for completing the task. Based on phrases and vocabulary items surrounding the topics of grief, mourning, and expressing one's condolences, the letter had to reflect elements of empathy and tactfulness. In addition, the time of origin of the letter had to be reasonably presented: did the narrator's mother write the letter shortly after the incident happened, or after the end of the war? If she wrote the letter immediately following the incident, the question of how she managed to send it to the U.S. during the time of rigorously-enforced Nazi censorship needed to be addressed. In the case of choosing the post-war timeframe for informing the relative, reasons for the hesitance should have been reflected upon in the letter.

In preparation of the play, two students volunteered to rework the letter they had written for class in order to turn it into a scene. ${ }^{14}$ In this particular scene, the narrator's mother reads the letter out loud to the audience. The participating students preferred to have Frau Rosner (Rosner was the chosen family name for the narrator's family, which is unnamed in the novel) write the letter right after Frau Schneider's death. They argued that a postponement of the time of origin of the letter would automatically result in placing the scene at the end of the plot, which they wanted to avoid for dramaturgical reasons. The group thought that concluding the plot with Friedrich's death, as described in the novel, would create a more convincing dramatic effect in terms of emphasizing the general catastrophe caused by the Nazis, rather than focusing on the personal guilt of Frau Rosner. In the scene the students created, Frau Rosner sat at a table facing

\footnotetext{
13 See Appendix D.

${ }^{14}$ For a copy of the letter within scene nine see Appendix E.
} 
the audience while reading Mr. Rosner the letter she had just written to the relatives. The scene ended with Mr. Rosner embracing his tearful wife.

I was pleasantly surprised by the creation of this scene's performance especially and by the students' involvement in the project overall. Aside from their constructive reflections on how to structure this particular scene, the students' language development and talent, as displayed in their acting out the characters they chose, were the most memorable elements of preparing and performing the play. The positive feedback we received from the audience, as well as the interest expressed by students in a future play, are also indicators of the success of the project.

\section{Conclusion}

The project of dramatizing Hans Peter Richter's novel Damals war es Friedrich has been a rewarding enterprise for several reasons. Not only did students improve their language abilities through performing and memorizing their speaking parts, but they also first-handedly encountered the advantages of looking beyond the scope of the classroom environment. The performance engaged more than 20 actively participating students and 70 people in the audience who tremendously enjoyed the combination of art and language learning. Aside from the pleasant experiences students and I had during the rehearsals and performance, the incorporation of a play into a foreign language learning environment proved to be a stimulating tool which increased students' progress in learning German.

In discussions I had with the students during the rehearsals and afterwards, they appreciated the possibility to apply their language knowledge to a discourse outside the classroom which called for a constant interaction between people in the target language. A survey conducted about a year later within the GUGD, in order to learn more about students' language learning experiences, showed that several students rated their participation in the play as the most rewarding project throughout their language studies.

For students who had not been able to take a German class during the semester that the play was practiced and performed, participation in the play turned out to be an excellent opportunity for them to continue to work on their languages skills. Students who had taken the Text in Context class prior to the play enjoyed discussing the differences between the script and the novel they had read in class. Those who had just started learning German or were taking an intermediate level class were surprised by how much they could actually do with the newly learned language. With the performance date approaching, even more students got involved in the project: creating and distributing a flyer announcing the play was a task they gladly volunteered to do.

Subsequent to the play, a number of former intermediate and advanced students became interested in taking the Text in Context course, in order to learn more about the topic of post-war Germany and Richter's novel. When I taught the course again within the framework of the annual GUGD summer program 
in Trier, Germany, students were eager to discuss the novel and compare it to the play, which some of them had attended or participated in.

Having had very positive experiences with students creating one scene on their own through incorporating the result of a former writing task into the play, I will rethink my approach in order to encourage students to write their own play version of "Damals war es Friedrich", or a play independent of Richter's novel. This could be done as part of a theater class and culminating in a performance of a play or scenes of a play. The annual "Theaterfest" organized by the Mount Holyoke College German Studies Department, whereby high school and college classes throughout western Massachusetts annually come together to perform scenes in front of a jury, could serve as a platform for the performance.

Overall, the success of the project encouraged students to continue with their study of German. In a time that sees the decrease of enrollment in foreign language programs all too often, this may be the most significant reason to offer drama and theater performances while teaching a foreign language in the future.

\section{Bibliography}

Bygate, Martin (1999): "Task as a context for the framing, reframing and unframing of language." System 27/1, 33-48

Bollag, Burton (9/2007): "Foreign-Language Departments Bring Everyday Texts To Teaching." The Chronicle of Higher Education 1-5. (printed version of the text available online at: http://chronicle.com/weekly/v54/i11/11a00103.htm)

Eigler, Friederike (2001): "Language and Content Articulation at College Level. Designing a Third-Year German Course for a Content-Oriented, Task-Based Curriculum." Unterrichtspraxis 34/2, 107-118

Georgetown University German Department Curriculum Website (2007) at:

http://www1.georgetown.edu/departments/german/programs/ undergraduate/curriculum/36465.html

Mislevy, Robert J. \& Steinberg, Linda S. (2002): "Design and analysis in task-based language assessment." Language Testing 19/4, 477-496

Richards, David \& Nowicki, Ursula (1998a): "In search of a viable learning theory to support genre-based teaching to adult migrants: Part 1." Prospect 13/1, 40-52

Richards David \& Nowicki, Ursula (1998b): "In search of a viable learning theory to support genre-based teaching to adult migrants: Part II." Prospect 13/2, 63-77

Richter, Hans P. (1961): Damals war es Friedrich. München: DTV

Ronke, Astrid (2005): "Wozu all das Theater? Drama and Theater as a Method for Foreign Language Teaching and Learning in High Education in the United States." (Dissertation abstracts) Berlin: Technische Universiät. 
Schewe, Manfred (1993; 2003): Fremdsprache inszenieren. Zur Fundierung einer dramapädagogischen Lehr- und Lernpraxis. Oldenburg: Didaktisches Zentrum, Universität.

Schiffrin, Richard M. and Schneider, Walter (1977): „Controlled and automatic human information processing. Detection, search, and attention.” Psychological Review 64, 1-66

Taguchi, Etsuo, Gorsuch, Greta J. \& Sasamoto, Evelyn (2006): "Developing Second and Foreign Language Reading Fluency and its Effect on Comprehension. A Missing Link." The Reading Matrix 6/2 (online) 


\section{A Appendix A}

\section{A.1 ALLGEMEIN: Bei Rechten, Geboten, Verboten spielen die Modalverben, können, sollen, dürfen, müssen und ihre Negationen eine wichtige Rolle}

Table 1: Wortfeld entwickelt und ergänzt in Gemeinschaftsarbeit des German Department, Georgetown University

\begin{tabular}{|c|c|}
\hline Jemandem das Recht geben, etwas zu tun & $\begin{array}{l}\text { ein Recht ausüben, } \\
\text { wahrnehmen }\end{array}$ \\
\hline zu etwas das/ein Recht haben & $\begin{array}{l}\text { Das Recht zur freien } \\
\text { Meinungsäußerung haben }\end{array}$ \\
\hline jemandem ein Recht zugestehen & ein Anrecht haben auf etwas \\
\hline \multicolumn{2}{|l|}{$\begin{array}{l}\text { ABER ... jemandem das Recht } \\
\text { entziehen/nehmen, etwas zu tun }\end{array}$} \\
\hline \multicolumn{2}{|l|}{ Der Rechtsentzug } \\
\hline jemanden eines Rechts berauben & $\begin{array}{l}\text { Die Juden wurden des Rechts } \\
\text { der freien Religionsausübung } \\
\text { beraubt }\end{array}$ \\
\hline \multirow[t]{2}{*}{ Jemandem etwas verbieten/untersagen } & $\begin{array}{l}\text { Es ist den Juden untersagt, } \\
\text { ins Konzert zu gehen }\end{array}$ \\
\hline & $\begin{array}{l}\text { = Man verbot ihnen, in Konzerte } \\
\text { zu gehen }\end{array}$ \\
\hline $\begin{array}{l}\text { Etwas milder: jemandem etwas } \\
\text { gestatten/nicht gestatten }\end{array}$ & $\begin{array}{l}\text { Es war ihm nicht mehr gestattet, } \\
\text { einen Friseur zu besuchen }\end{array}$ \\
\hline \multicolumn{2}{|l|}{$\begin{array}{l}\text { Die Rechte einer Person einsch- } \\
\text { ränken/beschränken/beschneiden/einengen }\end{array}$} \\
\hline \multicolumn{2}{|l|}{ die zunehmende Einschränkung der } \\
\hline \multicolumn{2}{|l|}{ Rechte } \\
\hline & \\
\hline
\end{tabular}

\section{A.2 RECHTE - VERBOTE - GEBOTE}


Table 2: Wortfeld Teil 2

\begin{tabular}{ll}
\hline (jemandem) etwas anordnen & $\begin{array}{l}\text { am 26. 4. } 38 \text { wurde angeordnet, dass } \\
\text { alle Juden ihr Vermögen angeben } \\
\text { sollten } \\
\text { = Den Juden wurde angeordnet, ihr } \\
\text { Vermögen anzugeben } \\
\text { Die Verordnung wurde am 15. 11. } \\
\text { bekanntgegeben. } \\
\text { Das Gesetz befahl innen das Tragen } \\
\text { eines Judensterns }\end{array}$ \\
etwas verordnen & $\begin{array}{l}\text { Der Staat gebot innen, ihre Betriebe } \\
\text { aufzulösen }\end{array}$ \\
$\begin{array}{l}\text { jemandem etwas befehlen } \\
\text { jemandem einen Befehl erteilen } \\
\text { formelle Ausdrucksweise) }\end{array}$ &
\end{tabular}




\section{B Appendix B}

\section{B.1 Zeittafel ${ }^{15}$}

Table 3: Zeittafel (Bei Gesetzen, Erlassen und Verordnungen sind die Veröffentlichungsdaten angegeben)

\begin{tabular}{|c|c|}
\hline 30. 01.33 & Adolf Hitler wird Reichskanzler. \\
\hline 05. 03.33 & Reichstagswahl, Einzelaktionen gegen Juden \\
\hline 24. 03.33 & $\begin{array}{l}\text { Der Reichstag ermächtigt Hitler, an seiner Stelle Gesetze zu } \\
\text { erlassen (Ermächtigungsgesetz) }\end{array}$ \\
\hline 01.04 .33 & Eintägiger Boykott jüdischer Geschäfte \\
\hline 07.04 .33 & $\begin{array}{l}\text { Nicht arische Beamte werden in den Ruhestand versetzt } \\
\text { (ausgenommen Kriegsteilnehmer) }\end{array}$ \\
\hline 21. 04.33 & Das rituelle Schächten wird verboten \\
\hline 25. 04.33 & $\begin{array}{l}\text { Die Neuaufnahme von Nichtariern an Schulen und Hochschulen } \\
\text { wird eingeschränkt }\end{array}$ \\
\hline 16. 06.33 & Im Deutschen Reich leben rund 500000 Juden \\
\hline 14. 07.33 & $\begin{array}{l}\text { "Unerwünschten" kann die deutsche Staatsangehörigkeit } \\
\text { aberkannt werden }\end{array}$ \\
\hline 02. 08.34 & $\begin{array}{l}\text { Reichspräsident von Hindenburg stirbt. Hitler macht sich als " } \\
\text { Führer und Reichskanzler" zum Staatsoberhaupt }\end{array}$ \\
\hline 16. 03.35 & Wiedereinführung der Wehrpflicht. \\
\hline 06. 09. 35 & Der Verkauf jüdischer Zeitungen im Straßenhandel wird verboten. \\
\hline 15. 09. 35 & $\begin{array}{l}\text { Nur Staatsangehörige deutschen und artverwandten Blutes } \\
\text { können "Reichsbürger" werden. Juden dürfen Staatsangehörige } \\
\text { deutschen Blutes nicht heiraten. Juden dürfen deutsche } \\
\text { Hausangestellte unter } 45 \text { Jahren nicht beschäftigen (Nürnberger } \\
\text { Gesetze) }\end{array}$ \\
\hline 30. 09. 35 & Alle jüdischen Beamten werden beurlaubt. \\
\hline 07. 03. 36 & $\begin{array}{l}\text { Juden besitzen kein Reichstagswahlrecht; Wiederbesetzung des } \\
\text { Rheinlandes. } \\
(\ldots)\end{array}$ \\
\hline
\end{tabular}

\footnotetext{
15 Taken from Richter, H.P. (1961): Damals war es Friedrich, München: DTV, 168pp.
} 


\section{Appendix C}

(Arbeitsblatt entwickelt und ergänzt in Gemeinschaftsarbeit des German Department, Georgetown University)

\section{C.1 Arbeit mit der Zeittafel}

Wenn wir von Menschenrechten sprechen, dann beziehen wir uns auf allgemeine Menschenrechte und spezifische Rechte, die man als Bürger eines Staates hat. Dazu zählen

- das Recht der freien Meinungsäußerung, das Recht der Versammlungsfreiheit, und die religiöse Freiheit

- das Recht auf Besitztum und Beruf

- das Recht auf Zugang zu Bildung, Ausbildung, Information

- das Recht auf eine Privatsphäre

- das Recht der Bewegungsfreiheit

- ein Anrecht auf den Schutz des Staates und auf rechtmäßige Verfahrensweisen

- Wahrnehmung der Rechte und Pflichten eines Staatsbürgers

Aufgabe (als Partneraufgabe gedacht)

Inhaltliche Arbeit

1. Studieren Sie die gesamte Zeittafel im Anhang von Damals war es Friedrich

2. Unterteilen Sie die genannten Daten/Ereignisse in drei Vierjahresabschnitte, 1933-37, 1937-41, 1941-45.

3. Wählen Sie eine der oben genannten Kategorien und finden Sie nach Möglichkeit in jedem Zeitabschnitt mindestens zwei bis drei Ereignisse oder Maßnahmen, die dieser Kategorie zugeordnet werden können. Kategorien überschneiden sich natürlich - Sie können also durchaus manche Punkte verschiedentlich kategorisieren.

Sprachliche Arbeit

in verschiedenen Bereichen. Nicht alles ist nötig, nicht alles ist möglich. Wichtig ist hier Variation und Flexibilität im Ausdruck.

1. Verwandeln Sie Nominalphrasen in Verbalphrasen

2. Variieren Sie die Verbalphrasen, z. B. Passiv in Aktiv, Passiv in andere Passivkonstruktionen, andere Formulierungen mit ähnlicher Bedeutung. 
3. Finden Sie Möglichkeiten, das Datum miteinzubeziehen,- machen Sie aus Ihren verschiedenen Daten eine kleine Story, zum Beispiel durch Nebensätze, oder Koordinationen.

4. Verwenden Sie nach Möglichkeit die Ausdrücke auf dem Handout Rechte - Verbote 


\section{Appendix D}

(Aufgabenstellung entwickelt und ergänzt in Gemeinschaftsarbeit des German Department, Georgetown University)

\section{D.1 Beileidsbrief an Frau Goldberg Aufgabe}

Stellen Sie sich vor, Sie sind Frau Rosner aus Damals war es Friedrich. Schreiben Sie einen Beileidsbrief an die Schwester der verstorbenen Frau Schneider, eine Ihnen unbekannte Frau Goldberg, deren Adresse Sie gefunden haben. Sie wollen Frau Goldberg über den Tod Ihrer Schwester informieren und ihr Ihr Beileid aussprechen. Sie wissen über Frau Goldberg nur, dass Sie bereits 1934 in die USA ausgewandert ist und jetzt in Los Angeles lebt. Der Tod von Frau Schneider hat Sie sehr beunruhigt, und Sie entschließen sich, diesen nicht einfachen Brief zu schreiben, der sowohl persönlich als auch distanziert gehalten sein muss. Da dieser Brief für Frau Goldberg wahrscheinlich völlig unerwartet ist, besteht der Brief nicht nur aus den typischen Komponenten eines Beileidbriefes:

- Mitteilung des Todes

- Beileid aussprechen

- Würdigung der Verstorbenen / Erinnerung an die Verstorbene

Noch dazu sind die folgenden Komponente zu beachten:

- Sichvorstellen u. Erklärung, wie Sie Frau Goldbergs Adresse bekommen haben

- Beschreibung der Umstände des Todes

- Darstellung Ihrer Rolle beim Tod

- Bezug auf die politische Situation in Deutschland

Inhalt

Bedenken Sie genau den Anlass, Grund und das Ziel Ihres Briefes. Die wichtigste Entscheidung hier ist, wann Sie diesen Brief schreiben, z. B. direkt nach dem Vorfall, vor 1945 oder nach 1945. Für alle drei Möglichkeiten gibt es gute Gründe. In jedem Fall beeinflusst diese Entscheidung aber sowohl, was Sie zum Ausdruck bringen wollen, als auch, wie Sie die Ereignisse um Frau Schneiders Tod interpretieren.

Bei dieser Interpretation hilft Ihnen einerseits die genaue Kenntnis der Textstelle in Damals war es Friedrich; andererseits müssen Sie Ihre tatsächlichen und auch Ihre unterlassenen Handlungen begründen und dazu aus Ihrer gegenwärtigen Situation Stellung nehmen. Hier sind insbesondere folgende Überlegungen wichtig: 
- Wie bezeichnen Sie den Tod - als Tod, als Totschlag, als Mord, als Überfall mit Todesfolgen, als Unfall, oder umgehen Sie gar das Problem, indem Sie das Wort ganz vermeiden?

- Welche Sprache verwenden Sie, um einerseits etwas sehr Persönliches, nämlich den Tod einer Nachbarin (oder Freundin?) mitzuteilen, und um andererseits die historischen Ereignisse, die sehr eng mit diesem Tod verknüpft sind, darzustellen? Ihre Interpretation des Nationalsozialismus und seiner Einstellung zu den Juden ist dabei zentral.

- Was hat (damals) Ihre Handlungen und Gefühle bestimmt; was wissen Sie heute und wie sehen Sie daher die Dinge?

- Wie stellen Sie Ihre eigene Rolle dar? Fühlen Sie sich schuldig, dass Sie nicht mehr geholfen haben, oder konnten Sie nicht anders handeln?

Auf jeden Fall werden Sie inhaltlich persönliche Erfahrungen und Gefühle mit relevanten politischen Ereignissen verbinden müssen. Das schlägt sich in der von Ihnen verwendeten Sprache nieder.

Sprachlicher Schwerpunkt

Diskursebene

- Komplexe Darstellung Ihrer Position als Briefeschreiberin, gegenüber Frau Schneider, gegenüber Frau Goldhagen, und auch gegenüber sich selbst.

- Darstellung der Ereignisse um Frau Schneiders Tod, besonders deren Reihenfolge und Ihre Interpretation (Kausalitäten, Konsequenzen).

- Ausdruck der menschlichen Verbindung zu Frau Goldhagen (e.g., Beileid, Trauer, Schuld) und plausibler Abschluss des Briefes

Satzebene

- Differenzierte Verwendung von Modalverben, Konjunktiv und Passiv, um Wissen, Schuld, Handeln oder Nichthandeln auszudrücken - oder auch, um sie zu verstecken.

- Vokabular zu historischen Ereignissen

- Komplexe Hauptsatz-/Nebensatzstrukturen und deren Variation

- Beachten der "Lieblingsfehler", z.B. Wortstellung, SV-Inkongruenz, Verbformen, Präpositionen

Sprachkonventionen

- Form des Briefes (Anrede, Verabschiedung) 
- Kommasetzung, Groß- und Kleinschreibung

- Getippte Umlaute

Schreibprozess

1. Brainstorming und Wortfeldarbeit (Trauer, Beileid, Vokabular zum Nationalsozialismus, Judenverfolgung, Holocaust, Briefeschreiben)

2. Entwurf und endgültige Fassung (jeweils mit Zeitangaben); Länge: 1 - 2 Seiten, doppelter Zeilenabstand

Benotungskriterien:

Die Kategorien Aufgabe, Inhalt und sprachlicher Schwerpunkt werden äquivalent gewichtet. Die Gesamtnote ergibt sich aus den Teilnoten. In der revidierten Version können Sie Ihre Note um maximal 2 "Stufen" verbessern (sehr gute Korrektur: Verbesserung um 2 Stufen; gute Korrektur: 1 Stufe, mittelmässige bis schwache Korrektur: keine Verbesserung der Note). 


\section{E Appendix E}

(Die Szene wurde erstellt in Zusammenarbeit von Lauren Ditty, Katarvia Taylor und Mark Lauer)

(Frau Rosner sitzt am Tisch und schreibt. Nach wenigen Augenblicken legt sie den Brief zur Seite und verbirgt Ihr Gesicht in Ihren Händen. Dann betritt Herr Rosner die Bühne und setzt sich zu Ihr. Er nimmt Sie in den Arm.)

Herr Rosner: Hast Du den Brief an Frau Schneiders Schwester geschrieben?

Frau Rosner. (Das Gesicht immer noch in den Händen):Ja, das hab' ich.

Herr Rosner: Möchtest Du ihn mir vorlesen.

Frau Rosner: Bitte.

(Sie nimmt den Brief zur Hand und beginnt langsam zu lesen)

Sehr geehrte Frau Goldberg,

mein Name ist Hilde Rosner und ich war für einige Jahre die Nachbarin Ihrer Schwester, Sarah Schneider. Ihre Schwester sprach oft von Ihnen und hat mir vor einiger Zeit Ihre Adresse gegeben, damit ich im Notfall einen Angehörigen kontaktieren kann. Nach den Begebenheiten der letzten Tage ist dieser Notfall nun leider eingetreten.

Ich muss Ihnen bedauerlicherweise mitteilen, dass ich die schmerzliche Pflicht habe, Sie vom Tod Ihrer lieben Schwester in Kenntnis zu setzen. Ich möchte Ihnen und Ihrer Familie mein tief empfundenes Mitgefühl aussprechen.

Ich verstehe, dass mein Beileidsbrief Ihre Trauer nicht mildern kann. Ich glaube aber, dass es sehr wichtig ist, dass Sie die Wahrheit erfahren, die den Tod Ihrer Schwester und die Deportation Ihres Schwagers betrifft. Ja, es ist die schreckliche Wahrheit, dass nicht nur Ihre Schwester Hitlers Horden zum Opfer fiel, sondern auch Ihr lieber Schwager, über dessen Verbleib wir nichts wissen.

In der Nacht, in der Ihre Schwester ums Leben kam, zog ein wütender Mob durch unsere Straßen, der jüdische Geschäfte zerstörte und in private Wohnungen eindrang. Niemand verhinderte die Zerstörungen. Ich war mit meinem Sohn und meinem Mann in unserer Wohnung, als wir den starken Lärm im Treppenhaus und in der Wohnung über uns hörten. Herr Resch, unser nationalsozialistisch gesinnter Hausbesitzer, führte einen aufgebrachten Pöbel zur Wohnung Ihrer Schwester. Ängstlich und nicht wissend, was wir tun sollten, blieben wir in unserer Wohnung. Als mein Mann wenig später nach dem Rechten schaute, war es schon zu spät. Ihre liebe Schwester erlag noch in der selben Nacht den schweren Verletzungen, die Ihr zugefügt wurden.

Ich wünschte, wir alle wünschten, dass wir etwas zur Hilfe Ihrer Schwester getan hätten. Die Situation im ganzen Land ist völlig außer Kontrolle geraten. Warum haben wir nichts getan? Aus Angst. 
Ich erwarte kein Verständnis für unsere unterlassene Hilfe oder gar Vergebung, möchte mich allerdings auch nicht vor meiner Schuld verstecken. Als Ihr lieber Schwager wenige Tage später abgeholt wurde, haben wir wieder tatenlos zugesehen. Gott sei Dank konnte Friedrich rechtzeitig fliehen und sich vor den Schergen Hitlers verstecken. Ich wünschte, wir könnten etwas für Ihn tun, aber wie Sie vielleicht wissen, hat sich der Antisemitismus in letzter Zeit immer mehr verstärkt. Die Rechte der jüdischen Bevölkerung wurden immer weiter eingeschränkt. Bald werden Juden in unserer Gesellschaft keine Rechte mehr haben. Betrachten Sie diesen Brief als mein Schuldeingeständnis der unterlassenen Hilfe. Ich werde mir selbst niemals vergeben können.

Ungewissheit kann schlimmer sein als eine Gewissheit - mag diese auch noch so schrecklich sein. Aus diesem Grund hoffe ich, dass dieser Brief Sie erreichen wird. Mein Mann, unser Sohn und ich fühlen den Schmerz, der mit dem Verlust Ihrer lieben Verwandten über Sie gekommen ist. Ich werde Ihre Schwester immer vermissen. Ihre Schwester war mehr als eine Nachbarin. Sie war eine Freundin. Gerade deshalb ist unser Verhalten noch beschämender.

Ich wünschte, dass ich sagen könnte, dass sich die Situation in Deutschland verbessert. Ich möchte aber nicht lügen. Deutschland ist nicht mehr sicher für Juden. Aus diesem Grund machen wir uns große Sorgen um Friedrich. Möge Gott ihm und uns allen beistehen.

In stiller Trauer,

Ihre Hilde Rosner

(Sie legt den Brief auf den Tisch und verbirgt sich weinend in den Armen von Herrn Rosner. Der Vorhang fällt). 